\title{
KINEMATICS OF REGIONAL SALT FLOW IN THE NORTHERN GULF OF MEXICO
}

\author{
Xavier Fort ${ }^{1}$ \& Jean-Pierre Brun ${ }^{2}$ \\ 1 g.o. logical consulting, Cesson-Sévigné, France. (xavier.fort@univ-rennes1.fr) \\ ${ }^{2}$ Géosciences Rennes, Rennes, France. (jean-pierre.brun@univ-rennes1.fr)
}

\begin{abstract}
Text: 7602 words, 53 references, 1 Table, 19 Figures. Abbreviated title: Kinematics of Salt Flow, Gulf of Mexico
\end{abstract}

\begin{abstract}
The kinematics of regional-scale salt flow in the northern Gulf of Mexico is analyzed using: i) a map of shelf break contours at the termination of successive depositional episodes, ii) the location and geometry of large-scale structures of the slope domain as imaged by seismics and iii) digital slope bathymetry. In the north margin, salt has flowed toward the SW since the Cretaceous, with three main stages of development prior to, during and after a massive salt extrusion in the Early Miocene time. The corresponding sequence of structural development is discussed using a laboratory model. Contrary to all previous interpretations that invoked sedimentary loading as the main driving force, the analysis of regional-scale salt flow implies that the salt tectonics of the northern Gulf of Mexico is predominantly controlled by gliding above the margin dip. The SW-directed salt flow indicates that the north margin of the northern Gulf of Mexico trends NW-SE, in agreement with plate kinematic models in which the Yucatan continental block has undergone a $45-60^{\circ}$ dextral rotation relative to its present orientation.
\end{abstract}

\section{Keywords}

Gulf of Mexico, salt tectonics, regional-scale salt flow, salt extrusion, salt nappe, shelf migration, sedimentary loading, minibasins, laboratory modelling

\section{Introduction}

The salt tectonics of Atlantic passive margins, like in Brazil (Demercian et al. 1993, Cobbold et al. 1995, Mohriak et al. 1995), West Africa (Duval et al. 1992, Spathopoulos 1996, Cramez \& Jackson 2000, Marton et al. 2000, Fort et al. 2004a), or East Canada (Keen \& Potter 1995, Hogg et al. 2001, Kidston et al. 2002), results from gravity instability driven by the combined effects of the oceanward gliding of the salt-sediment package and progressive sedimentary loading. The instability is triggered 
by a margin tilt due to thermal subsidence after the end of rifting (e.g. Fort et al. 2004a). As salt is very weak, the salt layer acts as a very efficient décollement between the basement and sedimentary overburden. In the updip part of the margin, the décollement layer undergoes simultaneous layerparallel shear and stretching. The sedimentary overburden is submitted to extension, resulting in various types of growth structures such as grabens, tilted blocks, rollovers and diapirs (Duval et al. 1992, Vendeville \& Jackson 1992, Mauduit et al. 1997, Mauduit \& Brun 1998, Fort et al. 2004a). As stretching increases, the salt layer progressively thins and loses its decoupling power; consequently, the updip extension migrates oceanward (Fort et al. 2004a). In the downdip part of the margin, the décollement layer undergoes layer-parallel shear combined with shortening and consequently, the salt layer progressively thickens. The sedimentary overburden is submitted to shortening, resulting in various types of contractional growth structures such as multiwavelength folds, thrusts and the extrusion of salt bodies, including large frontal salt nappes (Tari et al. 2001, Brun \& Fort 2004, Rowan et al. 2004, Hudec \& Jackson 2006,). These processes and the wide range of resulting structures, as well as their development in distinct domains, have been illustrated in Atlantic margins (Brun \& Fort 2008). Even if variations occur due to different geological histories in terms of continental rifting, margin subsidence and sedimentation dynamics, most of these margins basically display comparable bulk deformation patterns with extension updip and contraction downdip.

The northern Gulf of Mexico (GoM) (Fig. 1), where salt was deposited in the Jurassic, presents a dual situation (Worral \& Snelson 1989). In its northwest margin, long and straight normal faults and downdip contraction characterize the updip extension, whereas its north margin displays a more complicated situation. The main characteristics of the north margin include short and curved normal faults, dipping in various directions, and a massive extrusion of allochthonous salt bodies during the Cenozoic, as much as $8 \mathrm{~km}$ thick in places, on top of which are deposited shallow to very deep Pliocene to Quaternary minibasins (Fig. 1b). This led Diegel et al. (1995, p.145) to conclude their review of the tectono-stratigraphic framework with the following question: "Are Gulf Coast style allochthonous salt structures more common, but unrecognized, or are the scale and complexity of saltrelated structures in the Gulf Coast unique?” For nearly 20 years, this major structural difference in salt tectonic patterns between the GoM and Atlantic margins has captured attention. In terms of processes, whereas salt tectonics in Atlantic-type margins obviously results from the combined effects of gliding induced by margin dip and sedimentary loading, almost all (if not all) authors have argued that sedimentary loading is the main driving force for salt tectonics in the Gulf of Mexico. Their arguments were published at roughly the same time in regional reviews (e.g. Worral \& Snelson 1989, Diegel et al. 1995, Peel et al. 1995, Hall 2002), conceptual models (Schuster 1995, Rowan 1995) and both experimental and numerical dynamic modelling (Talbot 1992, 1993, Vendeville 2005, Gaullier \& Vendeville 2005, Gradmann et al. 2009). From this point of view, it is noteworthy that a debate arose concerning the regional transport direction -i.e. regional-scale salt flow. Hossack (1995) interestingly writes: "M. Rowan (personal communication 1994) believes it is impossible to find a regional 
transport direction in an area as complicated as the Gulf of Mexico, whereas Peel et al. (1995) have noted that the salt structures of the northern Gulf of Mexico can be interpreted as the amalgamation of three non-synchronous, two-dimensional, gravity-spreading systems. These systems are oriented parallel to the continental slope and have extension at their updip ends, contraction at their toes, and strike-slip transfer zones at their margins.” This debate can be solved only by the direct analysis of salt flow at the regional scale. This question is of importance as it has several direct consequences in exploration. Salt flow controls the sedimentary cover deformation and therefore sediment fairways and the location of depocentres. For the same reasons, it is also an important parameter to be considered in seismic interpretation, especially when local scale structures are as complex as they are in the GoM, and it is a requisite reference when attempting to balance cross-sections using the assumption of twodimensional area preservation (Dahlstrom 1969; see specific rules of section balancing in salt tectonics in Hossack 1995).

In the present paper, we describe and analyze the available data that provide direct information on the direction of salt flow at the scale of the whole north margin of the GoM. Two databases are used: (1) in the slope area, digital bathymetric data (NOAA multibeam bathymetric survey), and (2) in the shelf area, a map of shelf break contours at the termination of successive depositional episodes (Galloway et al. 2000). The shelf can stabilize when the underlying salt stops flowing, due to extreme thinning. This allows the shelf break to progressively migrate seaward. Irregularities in the shelf break contours correspond to transfer zones that provide information on salt flow direction. Slope bathymetry displays narrow strike-slip displacements between the minibasins. As most minibasins are floating on top of allochthonous salt (Fig. 1), their relative displacements directly depend on the underlying salt flow. Seismic data show that the same kinematic pattern also explains the deformation observed at deeper levels. Contrary to all previous studies, these different datasets indicate a very consistent pattern of regional-scale salt flow from NE to SW in the north margin. Based on the above, we propose a three-stage model for salt tectonics and we discuss its tectonic significance within the framework of the GoM opening.

\section{Kinematics of shelf break migration}

A basin cross-section of the north margin shelf (e.g. Fig. 1b) shows normal fault systems rooting in the basal Louann salt, which has been progressively sealed by younger sediments in a downdip direction. This illustrates a seaward shelf migration of approximately $250 \mathrm{~km}$ since the Cretaceous. This is also illustrated in a map view by the successive positions of the shelf break contours throughout time in the northern GoM (Galloway et al. 2000). This large shelf migration directly depends on salt tectonics.

\subsection{Shelf stability in a salt basin}


In a salt basin, a shelf can form and stabilize only if the salt layer underlying the sediments is not flowing or is only flowing at a very low rate. As long as the salt is thick enough to allow easy flow, the overlying sedimentary layers undergo extensional faulting and fault blocks are transported seaward (Fig. 2a). The shelf first forms on the landward side of the salt layer pinch-out. With ongoing seaward displacement of faulted sedimentary blocks, the salt layer progressively thins, thus allowing the shelf to stabilize and migrate seaward (Fig. 2b). Salt deformation can still continue below the shelf but at such a low rate that the sedimentary influx permanently compensates the thickness variations created. This is well illustrated in the north margin of the northern GoM where the basal salt is extremely thin, below the present day shelf (Fig. 1b). No significant relief related to deformation occurs in the shelf whereas active ground deformations are measured onshore, thus indicating seaward displacement (Dokka et al. 2006). In summary, the shelf break in a salt basin corresponds to a mechanical boundary between low and high strain rates in deforming salt.

\subsection{Transfer zones}

In most margins, sediments are transported almost parallel to the slope. Therefore, the shelf break trends almost perpendicular to margin dip controlled salt flow, as portrayed in Figure 2. As demonstrated by laboratory experiments (Mauduit et al. 1997, Fort et al. 2004b), the gliding rate increases with the thickness of the sediments deposited on top of the salt. When sediments arrive obliquely to the margin dip, the sediment thickness varies in a direction that is perpendicular to the direction of salt flow. As a direct consequence, the gliding rate varies along strike leading to segmentation in the extensional domains, separated by transfer zones parallel to the salt flow direction (Fig. 3). Where sediments are thicker, the gliding rate as well as salt layer thinning are faster. This results in a faster rate of shelf migration. Across several neighbouring extensional domains with different gliding rates, the contour of the shelf break then becomes undulated (Fig. 3)

\subsection{Shelf break migration}

In their outstanding synthesis of the Cenozoic sedimentation history of the northern GoM, Galloway et al. (2000) provide a map of 25 principal depositional systems, each of them being defined by a geographic and stratigraphic extent. For the purpose of the present work, this map is redrawn here in a simplified way showing each system with an arbitrary colour (Fig. 4). The terminations of depositional episodes represent the successive positions of the shelf break. They are identified by their age in Ma, according to the time scale presented by Berggren et al. (1995). Throughout the Cenozoic, the bulk of the sediments that infilled the northern GoM margins have been provided by five main extrabasinal axes: the palaeo Rio Grande (RD), Houston (HN), Red (RD), Central Mississippi (CM) and East Mississippi (EM) (Fig. 4). For more details, the reader is referred to Galloway et al. (2000).

Between the Cretaceous (65 Ma) and base Oligocene (33 Ma), the mean trend of the shelf break was stable, from SW-NE in Texas (northwest margin) to E-W in Louisiana (north margin) (Fig. 4). In 
this time interval, the shelf migrated approximately $150 \mathrm{~km}$, on average, toward the S or SE. Since the Oligocene, the shelf has displayed a twofold evolution. In the northwest margin, it continued to migrate toward the SE with almost the same SW-NE trend. In the northern margin, its evolution became rather complex. Firstly, a major change in the orientation and position of the shelf break occurred in the Middle Miocene (from 16 to 12 Ma in Fig. 4) in the north margin. To the west, the shelf break trend rotated from an E-W to WNW-ESE trend. To the east, the shelf break jumped close to its present-day position, keeping its SW-NE trend. Secondly, the shelf break contours became strongly curved locally, defining numerous NE-SW trending transfer zones (Fig. 3). This indicates that since the Oligocene, the north margin shelf has migrated in a SW direction, almost parallel to the northwest margin shelf. In addition, since the Middle Miocene (12Ma), the western end of the north margin shelf has migrated against the western margin shelf break (Fig. 4).

A time-space plot of the shelf break position in the northwest and north margins (Fig. 5) illustrates the different amounts and rates of shelf migration. In the northwest margin, the overall displacement reached approximately $230 \mathrm{~km}$ and the migration history alternated between accelerations and decelerations, with a mean rate of $0.35 \mathrm{~cm} \mathrm{y}^{-1}$. Low rates of shelf migration occurred in the Early to Middle Eocene, Late Oligocene to Early-Miocene and since the Middle Miocene. The highest rate of shelf migration occurred in the Late Eocene to Early Oligocene. In the north margin, the overall displacement reached approximately $440 \mathrm{~km}$ and the rate of shelf migration has progressively increased from the Late Eocene to the present day. Since the Middle Miocene, the mean migration rate has remained almost constant at approximately $1.8 \mathrm{~cm} \mathrm{y}^{-1}$.

In summary, the location, geometry and kinematics of shelf break migration show that the north and northwestern margins have strikingly different histories. Two diachronic major changes occurred in the Late Eocene-Early Oligocene in the northwest margin and in the Middle-Miocene in the north margin. The significance of this will be discussed in a further section. Since the Middle Miocene, the north margin shelf has migrated in a SW direction indicating a similar direction of salt flow in this northern GoM domain.

\section{Large-scale structures of the slope domain}

\subsection{The overall four-layer basin structure}

The Walker Ridge and Keathley Canyon seismic lines shown in Figure 6 illustrate the four-layer structure of the salt basin in the slope area. To better display the structures and to appreciate their mechanical significance, no vertical exaggeration is used. The overall structure is strikingly "flat" and consists of the following layers, from base to top: i) the Middle Jurassic autochthonous Louann salt pinches out to the southwest of Keathley Canyon (Fig. 6a); ii) a comprehensive pile of "lower" sediments, from the Jurassic-Cretaceous to the Lower Miocene, that has been locally folded during sedimentation (Figs. 6a and b) and later stretched (Fig. 6b); iii) a layer of allochthonous salt fed by diapirs cutting through the Cretaceous-Lower Miocene sediments (Fig. 6b) or a salt nappe extruded 
from a ramp (Fig. 6a); and iv) a layer of Late Miocene to Quaternary sediments forming minibasins (Figs. 6a and b).

In Keathley Canyon (Fig. 6a), the allochthonous salt nappe was mostly fed by a zone of salt extrusion above a ramp located at the nappe rear. The salt base rests on top of Lower MiocenePliocene sediments at a very low angle, indicating that salt was flowing very quickly during sedimentation.

In Walker Ridge (Fig. 6b), the allochthonous salt layer was fed by a series of salt walls located between large Cretaceous to Early Miocene rafts. Widespread evidence of normal faulting indicates that rafting and the associated salt diapirism resulted from regional-scale extension. Many of these rafts have sunk down to the base of the autochthonous Louann salt. Salt extruded from a series of salt walls form convergent salt sheets, classically called salt canopies, on top of the rafts. Synchronous sedimentation is cast in triangular-shape bodies whose apex corresponds to the sutures between convergent flowing sheets ( $\mathrm{S}$ in Fig. $6 \mathrm{~b}$ ). The flat attitude of the allochthonous salt base envelope, over distances larger than 100 km (Fig. 6b), also indicates, in Walker Ridge, that the extruding salt has been able to flow almost horizontally over very large distances. This can occur only if the flow is very fast and/or if the sedimentation rate is very low. The rate of sediment supply in the Early-Middle Miocene is in the medium range of values observed in the Gulf of Mexico (Galloway 2001). Therefore, it is more likely that salt flowed at a rather fast rate, as observed for the Keathley Canyon salt nappe (Fig. $6 a)$.

Sedimentary units have been deposited on top of allochthonous salt since the Late Miocene but are predominantly from the Pliocene-Pleistocene, forming either i) minibasins, a term introduced by Worral \& Snelson (1989), with variable maximum depths; or ii) large and thin horizontal layers above the thick salt (Fig. 6).

\subsection{Minibasins}

Minibasins are growth synclines that subside into allochthonous salt with a large spectrum of shapes, internal structures, and a maximum depth that can reach more than $6000 \mathrm{~m}$ (Fig. 6). Some minibasins do not show any internal deformation except for smooth synclinal bending that increases with depth, whereas others display internal deformation (either extensional or contractional), mostly in their lower part, indicating that folding and/or faulting (F and T in Fig. 6b) occurred during the earliest stages of development. Various internal unconformities can be observed such as channel-type sedimentary filling of erosional incisions, onlaps on top of the underlying bent layers or undeformed layers resting on top of the previously faulted or folded layers. Minibasins entirely surrounded by salt are more symmetrical than those whose base touches the sediments underlying the allochthonous salt. In some asymmetrical minibasins, the regular increase of layer dip with depth indicates that tilting develops progressively during subsidence. On the contrary, in other minibasins, unconformities indicate that tilting occurs as successive separated events. Close to the surface, minibasins are 
separated either by salt ridges, on top of which are located narrow deformation zones that can be observed on bathymetric maps, or by large tabular salt sheets covered by only few hundred metres of sediments -i.e. shallow salt- that correspond to the flat-top bathymetric highs. Narrow deformation zones observed on bathymetric maps show that salt ridges localize horizontal displacements between the minibasins. These elements show that minibasins have a strong variability in terms of structure and history, which more likely reflects the variability of their local conditions of development.

\subsection{Thrust and fold belts at the basin boundaries}

In the northwest margin, the Perdido fold belt (Fig. 1) is a domain of frontal shortening with fold axes trending NW-SE. The folds are concentric, symmetrical to asymmetrical, and cored by the autochthonous Louann salt (Worral \& Snelson 1989, Peel et al. 1995, Trudgill et al. 1999, Camerlo \& Benson 2006). The Upper Jurassic-Eocene layers were folded during the early Oligocene, with deformation possibly continuing into the earliest Miocene (Peel et al. 1995, Trudgill et al. 1999).

In the north margin, the classically called "Mississippi Fan fold belt", located along the Louann salt, pinches out between the Sigsbee Escarpment to the SW and the Mississippi fan to the NE (Fig. 1a). It is still considered by most authors as a frontal fold and thrust belt resulting from radial shortening of the strata deposited on top of the autochthonous Louann salt (Wu et al. 1990, Weimer \& Buffler 1992, Diegel et al. 1995, Peel et al. 1995, Rowan 1997, Rowan et al. 2000, Wu \& Bally 2000, Moore et al. 2001, Grando \& McClay 2003, Rowan et al. 2004).

In Walker Ridge and Green Canyon, these folds commonly i) have a mean NE-SW axis trend, ii) display an upward decrease of amplitude, iii) can be symmetrical or asymmetrical with an inverted limb either associated or not to a fault showing a thrust component of displacement, and iv) have a salt core. Some of these folds are affected by extension with local extensional reactivation of the associated thrust faults. A fold hinge extension commonly allows the formation of extensional diapirs. Folding started in the late Jurassic-Cretaceous with further amplification in the mid-late Miocene (Rowan et al. 2000, Grando \& McClay 2003). In the Pliocene-Pleistocene, these folds were partly buried below the advancing nappes of allochthonous salt and partly below sedimentation in the abyssal plain (Fig. 6d). Mapping from 3D seismics in Walker Ridge and Green Canyon shows that the fold axes define typical left-stepping en échelon patterns, indicating a sinistral strike-slip shear in the direction of the salt pinch-out. Contrary to most previous interpretations, this indicates that this fold belt is a sinistral strike-slip shear belt from Walker Ridge (to the SW) to Atwater Valley (to the NE) and not a frontal fold and thrust belt.

In Keathley Canyon, the Cretaceous to lower Miocene strata which were entirely covered by allochthonous salt, are affected by salt-cored folds whose amplitude decreases upward (Fig. 6). The fold axes trend NW-SE, parallel to the Sigsbee escarpment in this area. This fold belt, which trends almost perpendicular to the mean NE-SW trend of the Walker Ridge-Atwater Valley fold belt, was unknown until very recently. 


\subsection{Salt nappes}

The Keathley Canyon salt nappe (Fig. 6a) consists of a single frontal salt nappe whose emplacement started at the end of the Lower Miocene. The nappe front is nearly linear with a NW-SE trend. Salt extrusion occurred along a ramp zone with a mean NW-SE trend with a complex contractional structure. On top of the salt nappe, most minibasins are of Pliocene-Pleistocene age. However, some minibasins display a condensed Cretaceous section at their base. At the rear of the ramp zone, minibasins can be very deep with the base nearly reaching the Louann salt base (Fig. 6a). The overall displacement of the nappe is in the order of $120 \mathrm{~km}$ : roughly $80 \mathrm{~km}$ in Middle-Late Miocene and $40 \mathrm{~km}$ since the Pliocene.

The Walker Ridge and Green Canyon salt nappes (Figs. 6c and d) emplaced in the Pliocene and formed several lobate contours of the allochthonous salt edge that partly correspond to the Sigsbee escarpment. Their overall displacement can reach 30-40 km. Minibasins deposited on top of the nappe salt are Pliocene to Quaternary in age.

All salt nappes emplaced above an already folded footwall (see the previous section). The Keathley Canyon nappe displacement is approximately three times larger than the one of the Walker Ridge and Green Canyon nappes.

\section{Kinematics of allochthonous salt flow in the slope domain}

The analysis of seafloor deformation presented in this section was carried out using the NOAA multibeam bathymetric survey. The mean pixel size of images is approximately $60 \mathrm{~m}$. To make the visualisation, interpretation and mapping of seafloor structures easier, regardless of their orientation, we used a set of bathymetric images with artificial illuminations for different azimuths and plunges.

Over a distance of $450 \mathrm{~km}$ in an east-west direction, the bathymetric map (Fig. 6d) shows the margin slope morphology between the shelf break to the north and the Sigsbee escarpment to the south. The slope enlarges from less than $100 \mathrm{~km}$ in eastern Green Canyon to approximately $250 \mathrm{~km}$ in Garden Bank and Keathley Canyon to the west. The variations of local bathymetric relief, with amplitudes up to $100 \mathrm{~m}$, attest to the recent and still active deformation which gives three main types of first-order morphological features: i) minibasins expressed as bathymetric lows, whose contours range from polygonal to rounded with large variations in the aspect ratios; ii) narrow deformation zones separating the minibasins, corresponding to salt ridges, that are often bound by steep normal faults and which display second-order normal faults and sometimes en échelon folds or small diapirs; and iii) large and sinuous flat-top bands expressed as bathymetric highs corresponding to shallow salt. Most narrow deformation zones indicate that the underlying salt ridges correspond to strike-slip corridors accommodating relative horizontal displacements between the minibasins.

\subsection{Shape and orientation of the minibasins}


The mapping of shallow salt areas (Fig. 7) shows a series of striking features. To the north, the shelf-slope transitional zone is characterized by the presence of salt diapirs piercing the surface and flowing parallel to the slope. The eastern part of Green Canyon displays far fewer zones of shallow salt than the rest of the slope, largely due to thicker sedimentation. Minibasins separated by narrow deformed zones dominate in southern Garden Bank, Keathley Canyon and Walker Ridge. Shallow salt dominates within an oblique corridor that is $50-70 \mathrm{~km}$ wide, from SW Green Canyon to SE Keathley Canyon and SW Walker Ridge.

Almost half of the minibasins have rather rounded shapes with a small ellipticity ratio $\mathrm{L} / \mathrm{S}<2.3$, where $\mathrm{L}$ and $\mathrm{S}$ are the long and small basin axes, respectively. The long axis orientation shows a bimodal distribution with a major peak around $\mathrm{N} 135^{\circ}$ (Fig. 8b) corresponding to a majority of the most elongated basins -i.e. with ellipticity ratios L/S>2.3 (Fig. 8c). The second peak, with basin trends around $\mathrm{N} 50^{\circ}$ and which is nearly orthogonal to the major peak (Fig. 8b), corresponds to basins with ellipticity ratios $\mathrm{L} / \mathrm{S}<2.3$ (Fig. 8c). The identification on the slope map (Fig. 8a) of basins participating in the major peak around $\mathrm{N} 135^{\circ}$ (green colour in Figs. 8b and c) shows that they dominate to the west, in Garden Banks and Keathley Canyon. In this area they underline a dominant NW-SE structural trend.

\subsection{Kinematics of narrow deformation zones}

The kinematic analysis presented in this section is based on a detailed mapping of narrow deformation zones (Fig. 7). The internal structure of deformation zones was mapped with a mean variable spatial resolution of approximately $60 \mathrm{~m}$. The entire studied area was mapped twice and the results were compared. To eliminate a maximum of uncertainties, only the structures found in both maps were kept in the final version of the map.

Deformation zones were first separated into two classes according to the symmetry of the internal deformation -i.e. coaxiality of strain increments (Fig. 9). In zones of coaxial stretching, second-order normal faults have rather straight traces running parallel or near-parallel to the zone boundaries (Fig. 9a). In these zones, the principal direction of stretching is orthogonal to the zone borders. Zones of non-coaxial deformation are all those that do not correspond to the previous definition. More generally, they combine a component of strike-slip shear parallel to the zone borders with a component of stretching or shortening perpendicular to the zone borders (Fig. 9b), giving either zones of transtension (Fig. 10a) or transpression (Fig. 10b), respectively. Zones of coaxial stretching are, by far, the less numerous and are mostly located in the Keathley Canyon area. The principal directions of stretching deduced from these zones have a mean N50 trend (Fig. 11).

In zones of non-coaxial deformation, transtension (Fig. 10a) is by far the most commonly observed. It gives either systems of en échelon normal faults or pull-apart type structures. Only a few zones are slightly transpressional and give en échelon folds (Fig. 10b). In transtensional zones, the direction of stretching cannot be directly deduced from the orientation of the normal faults, as 
demonstrated by laboratory experiments on two-layer brittle-ductile models (Tron \& Brun 1991). However, the obliquity between normal faults and zone borders suggests a strike-slip shear (Fig. 9b).

The components of shear sense have been mapped using the shear sense indicators listed above (dextral/blue and sinistral/red in Fig. 11). At most places, dextral and sinistral senses of shear occur in zones defining conjugate-type patterns. However, few anomalies are detected. This is particularly true along the northern border of the studied area, close to the shelf break, where, as stated above, some salt diapirs pierce the surface and flow downslope as a salt glacier, partly covered by recent sediments. The lateral glacier borders give parallel shear zones with opposite senses of shear. As it is a surficial process, these shear zones have no direct relationship with the relative displacement of minibasins. Within the framework of our study, they are misleading and therefore, could have been omitted. Nevertheless, they were kept in Figure 11 as well as in the statistical treatment presented in the next section, where the results indicate that their relative weight in the whole dataset is rather small.

\subsection{Flow of shallow salt}

Shallow salt (Fig. 12), only covered by a few hundred metres of sediments, is expressed on the seafloor as bathymetric highs with irregular contours and with an average width of approximately 10 $\mathrm{km}$, but up to $30 \mathrm{~km}$ locally. In the slope central part, shallow salt dominates within a broad NE-SW oriented corridor that joins the Sigsbee escarpment at the limit between Keathley Canyon and Walker Ridge. The flat seafloor surface of the shallow salt displays deformation patterns made of small and narrow spaced normal faults (Fig. 12b), comparable to those observed at the surface of mountain glaciers (Lliboutry 1965, Paterson 1994; for a detailed comparison of glacial and salt patterns, see Talbot \& Pohjola 2009), which allow the direct mapping of the salt flow directions (Fig. 12a). In addition, ridges and crevasses that have also been observed in surficial salt flows of Iran typically trend at high angles to the direction of salt flow (Aftabi et al. 2010). To the east of the main corridor described above, small units of shallow salt tend to flow on top of the minibasins toward the S or SW, defining festoon-like contours with a mean E-W trend (represented with a thrust pattern in Fig. 12a). This component of salt flow has a small amplitude but consistently affects a rather large domain from SW Green Canyon (to the north) to the Sigsbee escarpment (at the limit between Keathley Canyon and Walker Ridge).

The flow pattern of shallow salt flow depicted in Figure 12 corresponds to a late component of slope deformation, superposed onto the main southwest direction of salt flow. It is related to the formation of the Walker Ridge salt nappe in the Pleistocene time.

\subsection{Statistical analysis of shear senses}

Domains of homogeneous deformation patterns were determined through a statistical analysis of the distribution of dextral and sinistral shear senses as a function of deformation zone orientation. Deformation zones were segmented into $5 \mathrm{~km}$-long units to obtain a weighted representation of the 
two types of shear sense as a function of their respective total length for a given range of orientation. These data were used to calculate rose diagrams. The whole studied area was divided into small domains, almost arbitrarily, and a rose diagram was calculated for each of them. Neighbouring domains with comparable statistical distributions were then merged, resulting in a final division into five domains as shown in Figure 13: Green Canyon I \& II, Walker Ridge III, Central IV and Keathley Canyon V. Statistical data for the five domains are summarized in Table 1.

To the east, the Green Canyon area is a corridor-like deforming domain bounded by the shelf break to the north and the Sigsbee escarpment to the south, showing a transverse reversal of the shear sense pattern. The rose diagrams show dextral shear parallel to the shelf break (Green Canyon II domain) and sinistral parallel to the Sigsbee escarpment (Green Canyon I domain), indicating that the bulk displacement pattern corresponds to a SW-directed channel flow. The dominant conjugate shears, sinistral trending $\mathrm{N}^{\circ}$ in Green Canyon I and dextral trending $\mathrm{N} 150^{\circ}$ in Green Canyon II, should likely result in mini-basin rotations that are dextral to the north and sinistral to the south. As the area is heavily sedimented, this is not directly imaged in the bathymetry.

Toward the west, the deforming domain enlarges considerably between the shelf break and Sigsbee escarpment, which becomes very lobate. However, as in Green Canyon, the shear sense patterns also display a reversal from the Central IV and Keathley Canyon V domains to the Walker Ridge III domain. The peaks of dextral and sinistral shear in Keathly Canyon and Walker Ridge correspond to those of Green Canyon II and I, respectively, but with a sinistral rotation of approximately $15^{\circ}$. This indicates that the mean $\mathrm{N}^{\circ} 5^{\circ}$ direction of channel flow in Green Canyon rotates to a mean $\mathrm{N} 50^{\circ}$ direction toward the southwest.

In the Central IV domain, the shear pattern is comparable to Green Canyon II and Keathley Canyon V, but with a sinistral rotation of the peaks that is even stronger than in Keathley Canyon. This central domain perturbation is a consequence of the small component of $\mathrm{S}$ to SSW flow, recorded in zones of shallow salt (see previous section) and related to the Walker Ridge nappe emplacement to the south in the Pleistocene.

The mean directions of flow deduced from the above analysis of the shear sense patterns for the five domains are in good agreement with the stretching directions deduced from the zones of coaxial deformation zones (Fig. 14), indicating an overall salt flow toward the southwest.

\section{Dynamics of salt tectonics in the northern Gulf of Mexico}

\subsection{Salt flow and salt extrusion}

The two fold belts of the north margin, in orthogonal contraction in Keathley Canyon and in sinistral strike-slip shear from Walker Ridge to Atwater Valley, developed close to the Louann salt pinch out -i.e. along basin edges- suggesting an initial rectangular shape of the salt basin. Simultaneous orthogonal shortening and strike-slip shear along two nearly perpendicular trends indicate a SW-directed flow of the autochthonous Louann salt at the regional-scale, since Mesozoic 
times. Up to the Early Miocene, salt flow, restricted inside the salt basin, led to a progressive thickening of the Louann salt layer, which is sometimes called "salt inflation" (e.g. Hall 2002). On top of the thickened salt, the sedimentary cover is condensed. At the end of the Early Miocene, failure occurred along the Keathley Canyon frontal ramp allowing salt to flow horizontally on top of the abyssal plain sediments, thus forming a large-scale salt nappe. This opening of a free boundary at the basin front simultaneously allowed a widespread extension to develop backward. The sedimentary cover was consequently stretched and segmented into rafts whose separation permitted the upward flow of salt and the feeding of large horizontal salt sheets. In a rather short time, between the Middle Miocene and early Late Miocene, the thickened Louann salt was transferred vertically to form a thick allochthonous salt layer on top of the rafts.

During necking of the sedimentary cover and before full raft rupture, salt was able to merge at some localized points. Extruded salt then first flowed in graben depressions between the rafts. This secondary salt flow direction, recorded by synsedimentary deposits, is orthogonal to the regional-scale flow direction. This relationship between the regional-scale (primary) and secondary salt flow is commonly observed in laboratory experiments, as shown in Figure 15. The regional salt flow controls the development of grabens in the sedimentary cover that initiate at high angles to the flow direction. Salt rising inside the opening grabens forms salt ridges. Where it locally pierces, salt flow is controlled by surface topography and, in particular, by surface depressions created by the grabens and therefore trending at high angles to the regional salt flow. Almost all previous studies in the GoM have interpreted this secondary salt flow direction, toward the S or SE, as the regional direction of salt flow. When the volume of extruded salt was large enough to entirely cover the rafts, the allochthonous salt became able to flow toward the SW, as a whole.

As a consequence of salt extrusion, the thinning of the Louann salt, sometimes called "salt deflation" (e.g. Hall 2002) or more commonly "salt withdrawal”, progressively brought Cretaceous to Early Miocene rafts into contact with the initial salt base (Fig. 6). The simultaneous sinking of rafts and extrusion of allochthonous salt allowed the formation of salt nappes along the lateral ramp of Walker ridge and Green Canyon in the Pliocene-Pleistocene (Fig. 16).

\subsection{Inferences from laboratory modelling}

Three top views of a laboratory experiment (Fig. 17) illustrate the relationship in time and space between the basin edge contraction, formation of frontal salt nappes and triggering of backward extension.

The general principles of model scaling and the experimental setting of such experiments have already been described in several papers (see Fort et al. 2004a \& b, Brun \& Fort 2004). The particular conditions of the present experiment are as follows. A double-wedge layer of silicone putty representing salt, with a $2 \mathrm{~cm}$ thickness in the middle, is deposited on top of a rigid plate (200 x 100 $\mathrm{cm}$ ) and covered by a $0.6 \mathrm{~cm}$ thick layer of sand representing the sediments. In Figure 17, the contours 
of the silicone layer pinch-out are shown by a white dotted line. For this experiment, which was not designed to specifically represent a particular margin, the subsidence was progressively applied to a basal plate whose angle of inclination was increased step-by-step during the first third of experiment duration. Therefore, the silicone putty predominantly glided downdip but with two small transverse components of flow converging toward the central axis of the model. Sedimentation was done once per day during a period of three weeks. In the three photographs shown here (Fig. 17), the pale and dark grey colours correspond to the two different sand colours used for syn-kinematic sedimentation.

At earlier stages of development (Fig. 17a), updip extension gave domains of small tilted blocks separated by transfer zones and a downdip foldbelt combining domains of coaxial shortening with parallel folds and domains of en échelon folds. With ongoing gliding, extensional structures were sealed by sedimentation updip. Downdip, the model is partitioned into one central and two lateral deforming domains with increasing shortening in the fold belts. Figure 17b shows rupture initiation in some of the earlier fold belts and the onset of the silicone putty extrusion. In the next stage (Fig. 17c), silicone nappes have displaced downdip and extension started to develop backward.

The sequence of downdip deformations leading to the formation of frontal salt nappe and backward extension observed in the laboratory model can be compared to the one identified in the north margin (Fig. 6a). In both cases, a long period of basin edge shortening preceded the ramp rupture, which allowed the extrusion of a nappe at the front and consequently backward extension.

\subsection{Relationship between slope deformation, shelf migration and rates of sedimentation.}

Cenozoic sedimentation rates in the northern GoM were always rather high and ranging between 1 and $7 \times 10^{4} \mathrm{Km}^{3} \mathrm{Ma}^{-1}$ (Galloway 2001). Within this framework of variations, rates that were high in the Palaeocene (5 $\left.\times 10^{4} \mathrm{Km}^{3} \mathrm{Ma}^{-1}\right)$ dropped down to low values during the Eocene (around 1-2 $\times 10^{4} \mathrm{Km}^{3}$ $\left.\mathrm{Ma}^{-1}\right)$. The major peak occurred in the Oligocene $\left(7 \times 10^{4} \mathrm{Km}^{3} \mathrm{Ma}^{-1}\right)$. The rates were medium in the Miocene (around $4 \times 10^{4} \mathrm{Km}^{3} \mathrm{Ma}^{-1}$ ) and reduced slightly in the Pliocene-Quaternary (around $3 \times 10^{4}$ $\mathrm{Km}^{3} \mathrm{Ma}^{-1}$ ) (Fig. 18a).

Shelf migration since the Middle Miocene as well as slope deformation since the Cretaceous indicate a regional-scale direction of salt flow directed toward the SW in the north margin. In other words, over a distance of approximately $400 \mathrm{~km}$ and for more than $100 \mathrm{Ma}$, salt has flowed in the same SW direction at a high angle to the main direction of the sedimentary supply in the area (Central Mississippi and mostly Eastern Mississippi. See Fig. 4). In the Middle Miocene, the sudden onset of shelf migration updip more likely resulted from the frontal ramp rupture in Keathley Canyon, without any obvious time relations with a sedimentary event (Fig. 18). The ramp rupture, releasing the salt flow downdip at the basin front, increased the rate of stretching and thinning of the salt updip (Fig. 2). Sediment load participated in the process, as shown by the development of transfer zones recorded in the shelf break contours (Figs. 3 and 4). However, the total lack of obvious time relations with a particular sedimentary event excludes the idea that sedimentary loading could have been a main 
driving force. These outstanding facts show that contrary to what has been advocated by most authors, if not all, salt tectonics in the GoM was not mainly driven by sedimentary loading. The permanence of SW-directed salt flow, irrespective of the sedimentation rates, therefore must have been predominantly controlled by the north margin SW dip.

\subsection{Salt kinematics and the opening of the Gulf of Mexico}

The northern GoM corresponds to the assemblage of two contrasted domains of salt tectonics. The northwest margin has a classical cylindrical structure with updip extension and downdip contraction. The regional-scale direction of salt flow is directed toward the SE, parallel to the mean direction of sedimentation input. The north margin also has a general structure with updip extension and downdip contraction, but is partly obscured by the massive extrusion of allochthonous salt. The regional-scale direction of salt flow is directed toward the SW, strongly oblique to the mean direction of sedimentation input. The final structure of the north margin is so strongly influenced by the structural effects of the massive salt extrusion and oblique sedimentary feeding of the basin that the mean SW direction of salt flow has been ignored for decades. In summary, the northern GoM is characterized by two mutually perpendicular senses of regional-scale salt flow, toward the SE and SW in the northwest and north margins, respectively. As salt flow is primarily driven by gliding down the margin dip, these two directions of salt flow indicate a SE-dipping northwest margin (something that has been known and admitted for a long time) and a SW-dipping north margin (which has, to our knowledge, never been proposed before). Nevertheless, a north margin orientation such as this provides new information about the opening of the GoM following the first plate kinematic model proposed by Pindell \& Dewey (1982). It is beyond the scope of the present paper to enter into this debate that has mobilized considerable arguments for almost 40 years -see the review of the models and arguments by Bird et al. (2005). We only would like to point out here that a $45-60^{\circ}$ dextral rotation of the Yucatan continental block relative to its present orientation fits well with a north margin trending NW-SE and dipping to the SW, as required by a SW-directed salt flow at the regional-scale.

The sinistral rotation model of the Yucatan continental block provides a simple explanation for the significant difference in the width of the northwest and north margins, as exemplified by the laboratory experiment shown in Figure 19a. For this experiment, a lithosphere model is built with sand to represent the brittle upper crust and sub-Moho mantle and with silicone putties to represent the ductile middle-lower crust and deep lithosphere mantle (for more details on the modelling of rifting in a four-layer brittle-ductile lithosphere, see Brun 1999, 2002). The model part corresponding to the Yucatan microplate is underlain by a rigid thin plate pulled at a constant rate around a vertical axis. The top view (Fig. 19) shows model surface deformation after a $30^{\circ}$ sinistral rotation. In this type of model, lithosphere stretching increases westward, almost linearly, such that continental breakup and/or mantle exhumation (Brun \& Beslier 1996) occurs to the west. Further rotation only separates the two already formed passive margins and would correspond to seafloor spreading. The model (Fig. 19a) 
shows a large domain of extension trending NW-SE and dipping to the SW that passes westward to a narrow margin trending roughly N-S. This is a fair comparison with the large-scale geology of the northern Gulf of Mexico (Fig. 19b). The two margins result from a combination of stretching and sinistral strike-slip shear but with a dominant stretching component to the north and a dominant strikeslip component to the northwest, ultimately resulting in a low dip and large margin to the north and a steeper and narrower margin to the northwest. This difference in margin structure is more likely responsible for the two different styles of salt tectonics observed.

\section{Conclusions}

Salt tectonics of the northern Gulf of Mexico is characterized by two regional-scale directions of salt flow toward the SE and SW in the northwest and north margins, respectively. In the northwest margin, updip extension and downdip contraction have functioned simultaneously since the earlier stages of deformation in the Cretaceous. In the north margin, three main stages must be considered in order to summarize the evolution and its relationships with the northwest margin:

(1) Up to the Early Miocene (Fig. 20a), the Louann salt was flowing toward the SW, thinning updip and thickening downdip against a NW-SE oriented frontal ramp located in NE Keathly Canyon and along a NE-SW oriented lateral ramp, from Walker Ridge to Atwater Valley (Fig. 20a). During this first stage, syn-sedimentary deformation in the slope area mostly consisted of folding with NW-SE axes in the frontal contraction zone and en échelon folding resulting from sinistral strike-slip shear along the lateral ramp. The position of the shelf at $18 \mathrm{Ma}$, cutting through the present-day offshore Louisiana, shows the updip limit of efficient salt flow at the end of this first stage.

(2) In the Middle Miocene (Fig. 20b), failure of the frontal ramp gave birth: i) frontward, to the Keathley Canyon salt nappe that emplaced on top of the abyssal plain sediments; and ii) backward, to widespread extension -i.e. rafting- of the Cretaceous to Early Miocene cover of the thickened Louann salt. Rafts separation allowed the salt to extrude and flow horizontally to form an allochthonous salt layer, as much as $8 \mathrm{~km}$ thick in places, on top of which Late Miocene to Pliocene sediments are deposited, thus forming minibasins that are locally very deep. To the NE, the shelf made a first fast jump toward the SW, indicating a downdip displacement of the domain of efficient salt flow. In Green Canyon-Atwater Valley, salt flow is channelized into a narrow corridor, bounded by the shelf to the NE and the salt basin boundary to the SW, considerably enlarging toward Walker Ridge.

(3) From the Pliocene to the present-day (Fig. 20c), the shelf made a strong and fast jump toward the west at the junction between the northwest and north margins, most likely due to interference between the two orthogonal salt flow directions. In the slope area, the allochthonous salt layer became thick enough to flow on top of the abyssal plain sediments forming the salt nappes of Walker Ridge and Green Canyon. In Keathley Canyon, the frontal 
nappe continued to flow toward the SW, reaching a bulk displacement of approximately 120 $\mathrm{km}$. The triangular shaped salt nappe of Alamino Canyon, which is located at the junction between the two margins, displaced southward likely as a result of the interference between the two orthogonal salt flows. To the east, salt flow strongly decreased in Atwater Valley but still continued in Green Canyon, as shown by evidence of a still active seafloor deformation.

The similar SW-directed salt flow given at once by the shelf migration, since the Middle Miocene, and the seafloor deformation in the slope, over $550 \mathrm{~km}$ from Louisiana to Keathley Canyon, is a first-order dynamic signal of salt tectonics in the northern GoM.

The overall pattern of regional-scale salt flow directed toward the SE in the northwest margin and toward the SW in the north margin indicates that the salt tectonics of the northern GoM is predominantly controlled by gliding above the margin dip. This conclusion is at odds with all previous interpretations that favoured sedimentary loading as the main driving force. From this point of view, the salt tectonics of the GoM is not different from what is observed in most salt margins around the world (e.g. Brazil: Demercian et al. 1993, Quirk et al. this volume; West Africa: Duval et al. 1992, Fort et al. 2004a; the North Sea: Stewart \& Coward1995): margin dip plays a primary role in salt tectonics (for a full discussion, see Brun and Fort submitted). Sedimentary loading participates in the process but does not drive it. This strongly suggests that SW-NE oriented regional balanced cross-sections should be referred to in future works. The above remarks also emphasize that the main difference between salt tectonics in the GoM and other margins is not the effects of sedimentary loading but the massive salt extrusion leading to a thick allochthonous salt layer, a problem that Diegel et al. (1995) has already clearly identified.

Finally, evidence for a SW-directed salt flow indicates that the north margin of the northern GoM is trending NW-SE. This brings a new piece to the debate concerning the initial position of the Yucatan peninsula, as proposed by Pindell and Dewey (1982).

\section{Acknowledgements}

We are extremely grateful to Statoil for support throughout the years and for authorization to publish this work. Despite our non-conventional view of salt tectonics in the Gulf of Mexico, we have benefited from considerable freedom of action, access to data and positive interactions with numerous people in Houston, London, Oslo, and Trondheim. We want to give special thanks to Nicholas Ashton, Rob Hunsdale and Tommy Mogensen Egebjerg for their confidence and help at various stages of this work. Great thanks are also due to Per Andreasen, Rob Hunsdale, Stephan Kosanke, Frode Moller Liestol, Fredrik Lynne Muller, Valente Ricoy Paramo, Gyrd Sundsbo, Bo Soderström, Terje Veum and Scott Young for driving us in the seismic complexity of the northern Gulf of Mexico and to Erik 
Finnström, Stephen Johnson and Bard Krokan who made this work possible. G.I Alsop and an anonymous reviewer are thanked for helpful reviews.

\section{References}

Aftabi P, Roustaie M., Alsop G.I. \& TAlbot C.J. 2010. InSAR mapping and modelling of an active Iranian salt extrusion. Journal of the Geological Society, 167, 155-170.

Berggren, W.A., Kent, D.V., Swisher, C.C. \& Aubry M.P. 1995. A revised Cenozoic geochronology and chronostratigraphy. In Berggren, W.A., Kent, D.V., Aubry M.P. \& HARDENBOL, J. (eds) Geochronology, time scales and global stratigraphic correlation. Society for Sedimentary Geology Special Publications, 54, 129-212.

Bird, D.E., Burke, K., Hall, S.A. \& CASEY, J.F. 2005. Gulf of Mexico tectonic history: hot spot tracks, crustal boundaries, and early salt distribution. American Association of Petroleum Geologists Bulletin, 89, 311-328.

BRUN J.-P. 1999. Narrow rifts versus wide rifts: inferences for the mechanics of rifting from laboratory experiments. Philosophical Transaction of the Royal Society, London, A, 357, 695-710.

BRUN J.-P. 2002. Deformation of the continental lithosphere: insights from brittle-ductile models. In Meer, S., Drury, M.R., De Bresser, J.H.P. \& Pennock, G.M. (eds) Deformation mechanisms, rheology and tectonics: Current status and future perspectives. Geological Society, London, Special Publications, 200, 355-370.

BRUN J.-P. \& BeSLIER, M.O. 1996. Mantle exhumation at passive margins. Earth and Planetary Science Letters, 142, 161-173.

BRUN J.-P. \& FORT X. 2004. Compressional salt tectonics (Angolan Margin). Tectonophysics, 382, 129-150.

BRUN J.-P. \& FORT X. 2008. Entre sel et terre. Structures et mécanismes de la tectonique salifère. Collection Interactions, Vuibert, Paris.

BRUN J.-P. \& FORT X. Submited. Salt tectonics at passive margins: geology versus models. Marine and Petroleum Geology. 
CAMERLO R.H. \& BeNSON E.F. 2006. Geometric and seismic interpretation of the Perdido fold belt: Northwestern deep-water Gulf of Mexico. American Association of Petroleum Geologists Bulletin, 90, 363-386.

Cobbold, P.R., Szatmari, P. Demercian, S. Coelho D. \& Rossello, E.A. 1995. Seismic and experimental evidence for thin-skinned horizontal shortening by convergent radial gliding on evaporites, deep-water Santos Basin, Brazil. In JACKson M.P.A., ROBERTS D.G. \& SNELson, S. (eds) Salt tectonics: a Global Perspective. American Association of Petroleum Geologists Memoir, 65, 305-321.

CrAmEZ, C. \& JACKSON, M.P.A. 2000. Superposed deformation straddling the continental-oceanic transition in deep-water Angola. Marine and Petroleum Geology, 17, 1095-1109.

DAHLSTROM, C.D.A. 1969. Geometric constraints derived from the law of conservation of volume and applied to evolutionary models for detachment folding. American Association of Petroleum Geologists Bulletin, 74, 336-344.

DEMERCiAn, S., SzATMARI, P. \& CoBbold, P. R. 1993. Style and pattern of salt diapirs due to thinskinned gravitational gliding, Campos and Santos basins, offshore Brazil. Tectonophysics, 228, 393433.

Diegel, F.A., KARLO, J.F. SCHUSTER, D.C., SHOUP R.C. \& TAUVERS, P.R. 1995. Cenozoic structural evolution and tectonostratigraphic framework of the northern Gulf Coast continental margin. In JACKSON M.P.A., ROBERTS D.G. \& SNELSON, S. (eds) Salt tectonics: a Global Perspective American Association of Petroleum Geologists Memoir, 65, 109-151.

DOKKA, R.K., SELLA, G.F. \& DiXON, T.H. 2006. Tectonic control of subsidence and southward displacement of southeast Louisiana with respect to stable North America. Geophysical Research Letters, 33, 1-5, L23308, doi: 10.1029/2006GL027250.

Duval, B., Cramez, C. \& JACKson, M.P.A 1992. Raft tectonics in the Kwanza Basin, Angola. Marine and Petroleum Geology, 9, 389- 404.

FORT X., BRUn J.-P. \& ChAuvel F. 2004a. Salt tectonics on the Angolan margin, synsedimentary deformation processes. American Association of Petroleum Geologists Bulletin, 88, 1523-1544. 
ForT X., BRUn J.-P. \& ChAUVel F. 2004b. Contraction induced by block rotation above salt. Marine and Petroleum Geology, 21, 1281-1294.

GALLOWAY, W.E. 2001. Cenozoic evolution of sediments accumulation in deltaic and shore-zone depositional systems, Northern Gulf of Mexico Basin. Marine and Petroleum Geology, 18, 10311040.

Galloway, W.E., GaneY-Curry, P.E., LI, X. \& Buffler, R.T. 2000. Cenozoic depositional history of the Gulf of Mexico basin. American Association of Petroleum Geologists Bulletin, 84, 1743-1774.

Gaullier, V. \& VendeViLLe, B.C. 2005. Salt tectonics driven by sediment progradation. Part II: Radial spreading of sedimentary lobes prograding above salt. American Association of Petroleum Geologists Bulletin, 89, 1081-1089.

Gradmann, S., BEAumont, C. \& Albertz M. 2009. Factors controlling the evolution of the Perdido Fold Belt, northwestern Gulf of Mexico, determined from numerical models, Tectonics, 28, TC2002, doi:10.1029/2008TC002326.

GrANDO, G. \& McClay, K. 2004. Structural evolution of the Frampton growth fold system, Atwater Valley- southern Green Canyon area, deep water Gulf of Mexico. Marine and Petroleum Geology, 21, 889- 910.

HALL S.H. 2002. The role of autochthonous salt inflation and deflation in the northern Gulf of Mexico. Marine and Petroleum Geology, 19, 649-682.

HogG J.R., DolPh D.A., MACKIDD D. \& Michel K. 2001. Petroleum systems of the deep water Scotian Salt Province, offshore Nova Scotia, Canada. GCSSEPM Foundation 21th Annual Research Conference, 23-34.

HossACK, J. 1995. Geometric rules of section balancing for salt structures. In JACKSON M.P.A., Roberts D.G. \& Snelson, S. (eds) Salt tectonics: a Global Perspective. American Association of Petroleum Geologists Memoir, 65, 29-40.

HUDEC M.R. \& JACKSON M.P.A. 2006. Advance of allochthonous salt sheets in passive margins and orogens. American Association of Petroleum Geologists Bulletin, 90, 1535-1564. 
Keen, C.E. \& Potter, D.P. 1995. Formation and evolution of the Nova Scotian rifted margin: evidence from deep seismic reflection data. Tectonics, 14, 918-932, doi:10.1029/95TC00838

Kidston, A.G., Brown, D.E., Altheim, B. \& Smith, B.M. 2002. Hydrocarbon potential of the deep-water Scotian slope. Canada-Nova Scotia Offshore Petroleum Board.

LliboutRy L. 1965. Traité de glaciologie. Tome 2: Glaciers, variations du climat, sols gelés. Masson, Paris.

MARTON, L.G., TARI, G.C. \& LehMAnN, C.T. 2000. Evolution of the Angolan passive margin, West Africa, with emphasis on post-salt structural styles. In MOHRIAK W. \& TALWANI, M. (eds) Atlantic rifts and continental margins. American Geophysical Union Geophysical Monograph, 115, 129-149.

MAUdUIT, T. \& BRUN, J.-P. 1998. Growth fault/rollover systems: Birth, growth, and decay. Journal of Geophysical Research, 103, 119-136.

MAuduit, T., GUERIN, G., BRUn, J.-P. \& LECANU, H. 1997. Raft tectonics: The effects of basal slope value and sedimentation rate on progressive extension. Journal of Structural Geology, 19, 1219-1230.

Mohriak, W.U., Macedo, J.M., Castellani, R.T., Rangel, H.D., Barros,. A.Z.N., Latgé, M.A.L., RicCi, J.A., Misuzaki, A.M.P., SzATMARI, P., DEMERCiAn, L.S., Rizzo, J.G. \& AireS, J.R. 1995. Salt tectonics and structural styles in the deep-water province of the Cabo Frio region, Rio de Janeiro, Brazil. In JACKson M.P.A., RoBerts D.G. \& Snelson, S. (eds) Salt tectonics: a Global Perspective. American Association of Petroleum Geologists Memoir, 65, 273-304.

Moore M.G., Apps G.M. \& Peel F.J. 2001. The petroleum system of the Western Atwater Foldbelt in the Ultra Deep Water Gulf of Mexico. GCSSEPM Foundation 21th Annual Research Conference, 369-380.

PATERSON W.S.B. 1994. The physics of glaciers. Pergamon, New York.

PeEL, F. J., TRAVIS, C.J. \& HossaCK, J.R. 1995. Genetic structural provinces and salt tectonics of the Cenozoic offshore U.S. Gulf of Mexico: A preliminary analysis. In JACKSON M.P.A., ROBERTS D.G. \& SNELson, S. (eds) Salt tectonics: a Global Perspective. American Association of Petroleum Geologists Memoir, 65, 153- 175. 
PindeLL, J.L. \& DeWey, J.F. 1982. Permo-Triassic reconstruction of western Pangea and the evolution of the Gulf of Mexico/Caribbean region. Tectonics, 1, 179-211.

Quirk, D., RAven, M., Hsu, D., Nielsen, M., Ings, S. J., LAssen, B. \& SchøDT N. this volume. Extensional salt tectonics on passive margins: examples from Santos, Campos and Kwanza basins.

RowAN, M.G. 1995. Structural styles and evolution of allochthonous salt, central Louisiana outer shelf and upper slope. In JACKSON M.P.A., ROBERTS D.G. \& SNELSON, S. (eds) Salt tectonics: a Global Perspective. American Association of Petroleum Geologists Memoir, 65, 199- 228.

RowAN, M.G. 1997. Three-dimensional geometry and evolution of a segmented detachment fold, Mississippi Fan foldbelt, Gulf of Mexico. Journal of Structural Geology, 19, 463-480.

RowAN, M.G., TRUDGILL, B.D. \& FIDUK, J.C., 2000. Deep-water, salt-cored foldbelts: lessons from the Mississippi Fan and Perdido foldbelts, northern Gulf of Mexico. In MOHRIAK W. \& TALWANI, M. (eds) Atlantic rifts and continental margins. American Geophysical Union Geophysical Monograph, 115, 173-191.

RowAN, M.G., Peel, F.J. \& Vendeville, B.C. 2004. Gravity driven fold belts on passive margins. In McClay,K.R. (ed) Thrust tectonics and hydrocarbon systems. American Association of Petroleum Geologists Memoir, 82, 157-182.

SCHUSTER, D.C., 1995. Deformation of allochthonous salt and evolution of related salt-structural systems, eastern Louisiana Gulf Coast, In JACKSON M.P.A., ROBERTS D.G. \& SNELSON, S. (eds) Salt tectonics: a Global Perspective. American Association of Petroleum Geologists Memoir, 65, 177198.

Spathopoulos, F. 1996. An insight on salt tectonics in the Angola Basin, South Atlantic. In AlsoP, G.I., Blundell, D.J. \& DAvison, I. (eds) Salt Tectonics. Geological Society, London, Special Publications, 100, 153-174.

TALBOt, C.J. 1992. Centrifuged models of Gulf of Mexico profiles: Marine and Petroleum Geology, 9, 412-432.

TALBOT, C.J. 1993. Spreading of salt structures in the Gulf of Mexico. Tectonophysics, 228, 151-166.

TAlBot, C.J., PohJOLA, V. 2009. Subaerial salt extrusions in Iran as analogues of ice sheets, streams 
and glaciers. Earth-Science Reviews, 97, 155-183.

TARi G.C., Ashton P.R., Coterill K.L., Molnar J.S., SORgenfrei M.C., ThOMPSON P.W.A., VALASEK D.W. \& Fox J.F. 2001. Examples of Deep-Water Salt Tectonics from West Africa: Are analogs to the Deep-Water Salt-Cored Foldbelts of the Gulf of Mexico? GCSSEPM Foundation 21th Annual Research Conference, 251-270.

TRON V. \& BRUN J.-P. 1991. Experiments on oblique rifting in brittle-ductile systems. Tectonophysics, 188, 71-84.

Trudgill, B.D., Rowan, M.G., FiduK, J.C., WeIMER, P., GALE, P.E., KorN, B.E., PHAIR, R.L., GAFFord, W.T., RoBerTs, G.R., DobBS, S.W., 1999. The Perdido fold belt, northwestern deep Gulf of Mexico, part 1: structural geometry, evolution and regional implications. American Association of Petroleum Geologists Bulletin, 83, 88-113.

VENDEVILLE, B.C. 2005. Salt tectonics driven by sediment progradation: Part I-Mechanics and kinematics. American Association of Petroleum Geologists Bulletin, 89, 1071-1079.

VENDEVILLE, B.C. \& M.P.A. JACKSON, 1992. The rise of diapirs during thin-skinned extension. Marine and Petroleum Geology, 9, 331- 353.

WORRALL, D.M., \& SNELSON, S. 1989. Evolution of the northern Gulf of Mexico, with emphasis on Cenozoic growth faulting and the role of salt. In BALLY, A.W. \& PALMER, A.R. (eds) The geology of North America- An overview. Geological Society of America, 97-138.

Weimer, P. \& BufFLER, R., 1992. Structural geology and evolution of the Mississippi Fan Fold Belt, deep Gulf of Mexico. American Association of Petroleum Geologists Bulletin, 76, 225-251.

WU, S. \& BALLY, A.W. 2000, Slope tectonics - Comparisons and contrasts of structural styles of salt and shale tectonics of the Northern Gulf of Mexico with shale tectonics of Offshore Nigeria in Gulf of Guinea. In MoHriaK W. \& TAlWANI, M. (eds) Atlantic rifts and continental margins. American Geophysical Union Geophysical Monograph, 115, 151-172.

Wu, S., BALly, A.W. \& CRAMEZ, C. 1990. Allochthonous salt, structure and stratigraphy of the 
northeastern Gulf of Mexico: Part II- Structure. Marine and Petroleum Geology, 7, 334- 370.

\section{Table and figure captions}

Table 1 Statistical data for the five domains of deformation (see location in Figure 13). In the last column, the percentages refer to the dextral and sinistral senses of shear, which were calculated separately.

Figure 1 (a) Schematic map of the northern Gulf of Mexico (modified after Diegel et al. 1995), with arrows showing the mean transport direction for the three spreading systems described by Peel et al. (1995). (b) Regional N-S transect. (modified from Peel et al. 1995). See location in Figure 1a.

Figure 2 Tri-dimensional block diagrams showing the two stages (a and b) of shelf migration, with sediment input parallel to the salt flow.

Figure 3 Tri-dimensional block diagrams showing the effect of sediment input oblique to the salt flow with development of transfer zones.

Figure 4 Kinematics of shelf migration in the northern Gulf of Mexico. Termination contours of depositional episodes represent the successive positions of the shelf break (redrawn after Galloway et al. 2000), identified by their age in Ma, according to the time scale presented by Berggren et al. (1995). Thick lines represent transfer zones (see Fig. 3) that mainly developed from the Miocene to the present day. The bulk of the sediments that infilled the northern GoM margins have been provided by five main extrabasinal axes indicated by arrows: palaeo Rio Grande (RD), Houston (HN), Red (RD), Central Mississippi (CM) and East Mississipi (EM).

Figure 5 Time-space profiles of shelf migration in the northwest (a) and north (b) margins. See location in Figure 4. 
Figure 6 Line drawings of regional seismic sections showing some of the major structures in the slope area of the north margin. (a) Keathley Canyon salt nappe. (b) Section of Walker Ridge showing the four-layer structure. S: Suture between the salt sheets. T: Thrust fault. F: Fold. (c) Walker Ridge salt nappe. (d) Location of sections a, b and c.

Figure 7 Map of the faults and folds that deform the seafloor and of the shallow salt (yellow) (bathymetric data from NOAA).

Figure 8 Orientation of minibasins in the north margin slope (bathymetric data from NOAA). (a) Map identification (green) of minibasins whose long axis trends around N135․ (b) Frequency diagram showing the bimodal distribution of the minibasin long axis direction, with a dominant population around a N135 ${ }^{\circ}$ peak (green). (c) Distribution of the minibasin ellipticity ratio L/S, with L and S being the long and small axes, respectively. The green band corresponds to the minibasin population identified in $b$, which also shows the highest ellipticity ratio values.

Figure 9 Seafloor images of zones of coaxial (a) and non-coaxial (b) stretching (bathymetric data from NOAA).

Figure 10 Tri-dimensional diagrams showing structures in zones of transtension (a) and transpression (b) on top of salt ridges.

Figure 11 Map of stretching directions (yellow bar) in zones of coaxial deformation and senses of shear (dextral/blue and sinistral/red) in zones of non coaxial deformation (bathymetric data from NOAA).

Figure 12 (a) Map of stretching directions in zones of shallow salt and festoon-like contours (thrustlike pattern) of salt flowing on top of the minibasins. (b) Seafloor image showing that zones of shallow salt correspond to flat bathymetric highs affected by small and narrow spaced normal faults (bathymetric data from NOAA).

Figure 13 The five domains of homogeneous shear sense patterns in the north margin. The rose diagrams show the direction frequency of dextral/blue and sinsitral/red senses of shear. The external 
circle of rose diagrams represents $30 \%$ of the data. See Table 1 for statistical data.

Figure 14 Comparison between the stretching directions in the zones of coaxial deformation and the mean directions of displacement for the analysis of the five domains of shear senses (see Fig. 13)

Figure 15 Top view of a laboratory model showing the relationship between regional-scale and secondary salt flows (salt is used here for silicone putty). The regional-scale flow, toward the left, is controlled by basal slope. Salt is extruded through ridges that form within graben trending at high angles to the regional-scale salt flow. The extruded salt flows according to the local surface slope and/or within the surface depression associated to grabens through which salt rises. Taking into account only this secondary flow direction could give misleading interpretations by approximately $90^{\circ}$.

Figure 16 (a) Sketch diagram showing the relation between the contraction related to the Keathley Canyon frontal ramp and en échelon folds and faults along the Walker Ridge-Atwater Valley lateral ramp, prior to the Middle Miocene. (b) Restoration of the Walker Ridge section (Fig. 6b) showing that the Middle Miocene extension following failure of the frontal ramp developed on top of earlier folds.

Figure 17 Top views of a laboratory experiment illustrating (a) updip extension and downdip contraction at an early stage of gliding, (b) the onset of a silicone (salt) nappe extrusion at the frontal ramp, and (c) the silicone nappe advance and simultaneous of backward extension allowing salt extrusion inside the silicone (salt) basin. Note the diapir extrusion along the shelf break in the updip part of the model in b and c.

Figure 18 Relationship in time and space between the (a) volume rate of sediment input (after Galloway 2001), (b) formation and failure of the frontal ramp and salt nappe advance, and (c) shelf migration (see profile b location in Fig. 4).

Figure 19 Opening of the Gulf of Mexico. (a) Top view of a lithosphere-scale experiment (four-layer brittle-ductile model made with sand and silicone putty) simulating the rifting in rotation around a pole 
located to the right The experiment was stopped at the continental breakup stage after a $30^{\circ}$ sinistral rotation. Arrows indicate the mean margin dips. See text for explanation. (b) Simplified geological map of the Gulf of Mexico showing the difference in width between the northwestern and north margins of the northern gulf.

Figure 20 Three-stage evolution model of the northern Gulf of Mexico. Situation (a) in the Early Miocene, (b) from the Middle Miocene to the Pliocene and (c) from the Pliocene to the present day. AC: Alamino Canyon, AV: Atwater Valley, GB: Garden Banks, GC: Green Canyon, KC: Keatley Canyon and WR: Walker Ridge. 


\begin{tabular}{|c|c|c|c|c|}
\hline Domains & Shear Sense & $\begin{array}{l}\text { Total zone } \\
\text { length }\end{array}$ & $\begin{array}{l}\text { Peak max. } \\
\text { Orientation }\end{array}$ & $\begin{array}{l}\text { Peak max. } \\
\text { Pourcentage }\end{array}$ \\
\hline \multirow{2}{*}{ Green Canyon I } & Dextral & $220 \mathrm{~km}$ & $\mathrm{~N} 330^{\circ}$ & $59 \%$ \\
\hline & Sinistral & $150 \mathrm{~km}$ & $\mathrm{~N} 60^{\circ}$ & $40 \%$ \\
\hline \multirow{2}{*}{ Green Canyon II } & Dextral & $70 \mathrm{~km}$ & $N 75^{\circ}$ & $64 \%$ \\
\hline & Sinistral & $70 \mathrm{~km}$ & $\mathrm{~N} 180^{\circ}$ & $50 \%$ \\
\hline \multirow{2}{*}{ Walker Ridge III } & Dextral & $200 \mathrm{~km}$ & $\mathrm{~N} 130^{\circ}$ & $70 \%$ \\
\hline & Sinistral & $175 \mathrm{~km}$ & $\mathrm{~N} 45^{\circ}$ & $57 \%$ \\
\hline \multirow{2}{*}{ Central IV } & Dextral & $215 \mathrm{~km}$ & $\mathrm{~N} 30^{\circ}$ & $52 \%$ \\
\hline & Sinistral & $395 \mathrm{~km}$ & N $150^{\circ}$ & $64 \%$ \\
\hline \multirow{2}{*}{$\begin{array}{l}\text { Keathley } \\
\text { Canyon V }\end{array}$} & Dextral & $275 \mathrm{~km}$ & $\mathrm{~N} 60^{\circ}$ & $55 \%$ \\
\hline & Sinistral & $530 \mathrm{~km}$ & N 165 & $69 \%$ \\
\hline
\end{tabular}




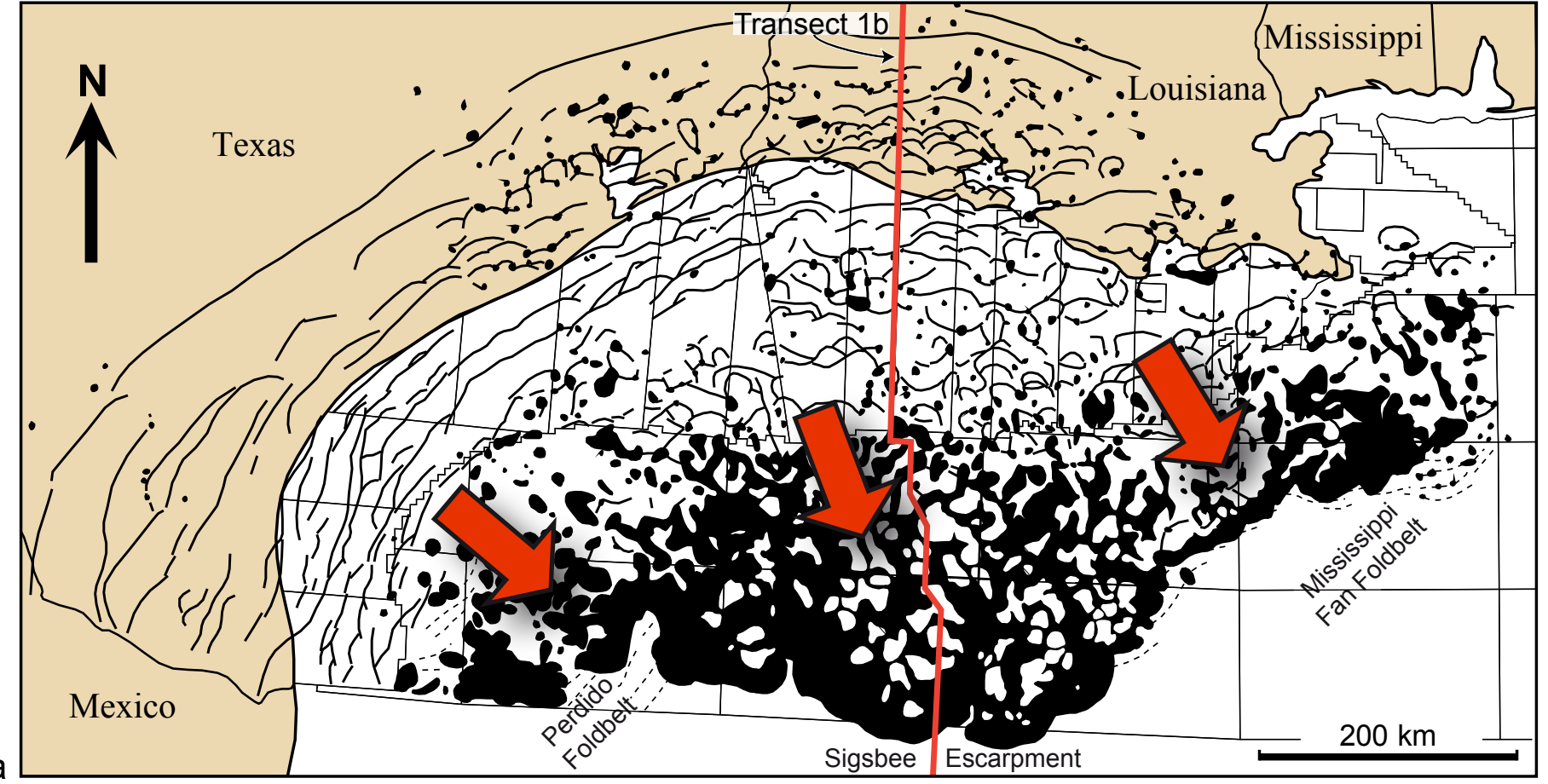

Eocene Oligocene Miocene Coastline Pliocene

Pleistocene - Recent 
Transported
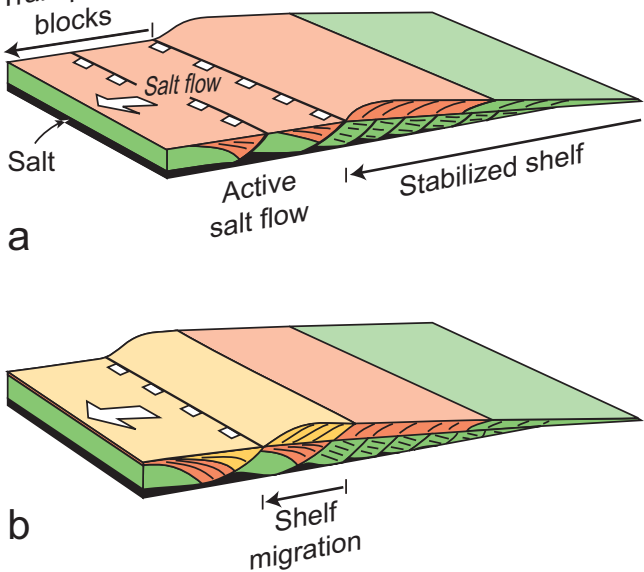
Oblique sediment input

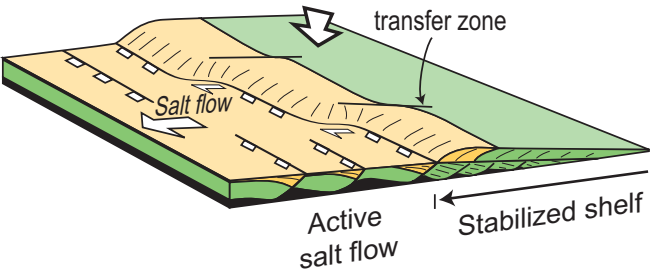




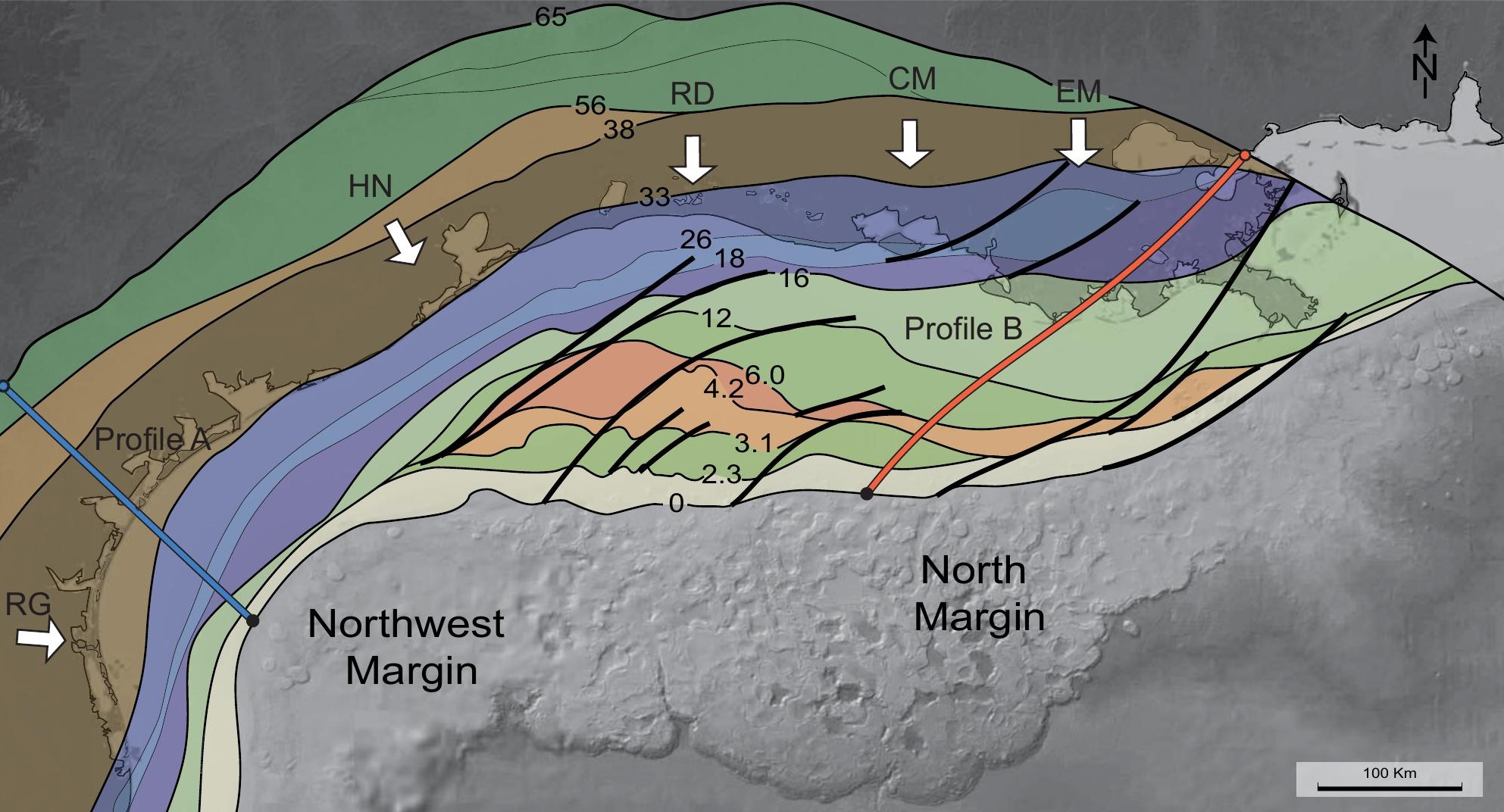




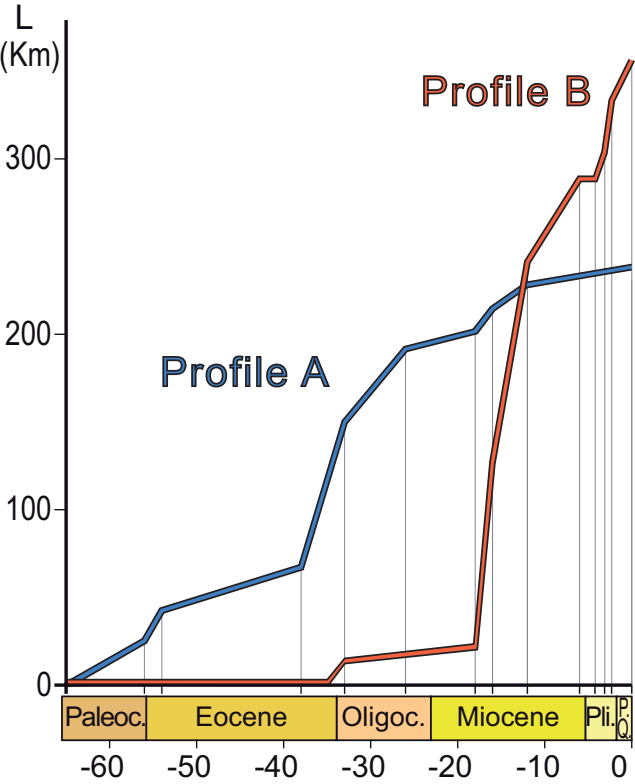





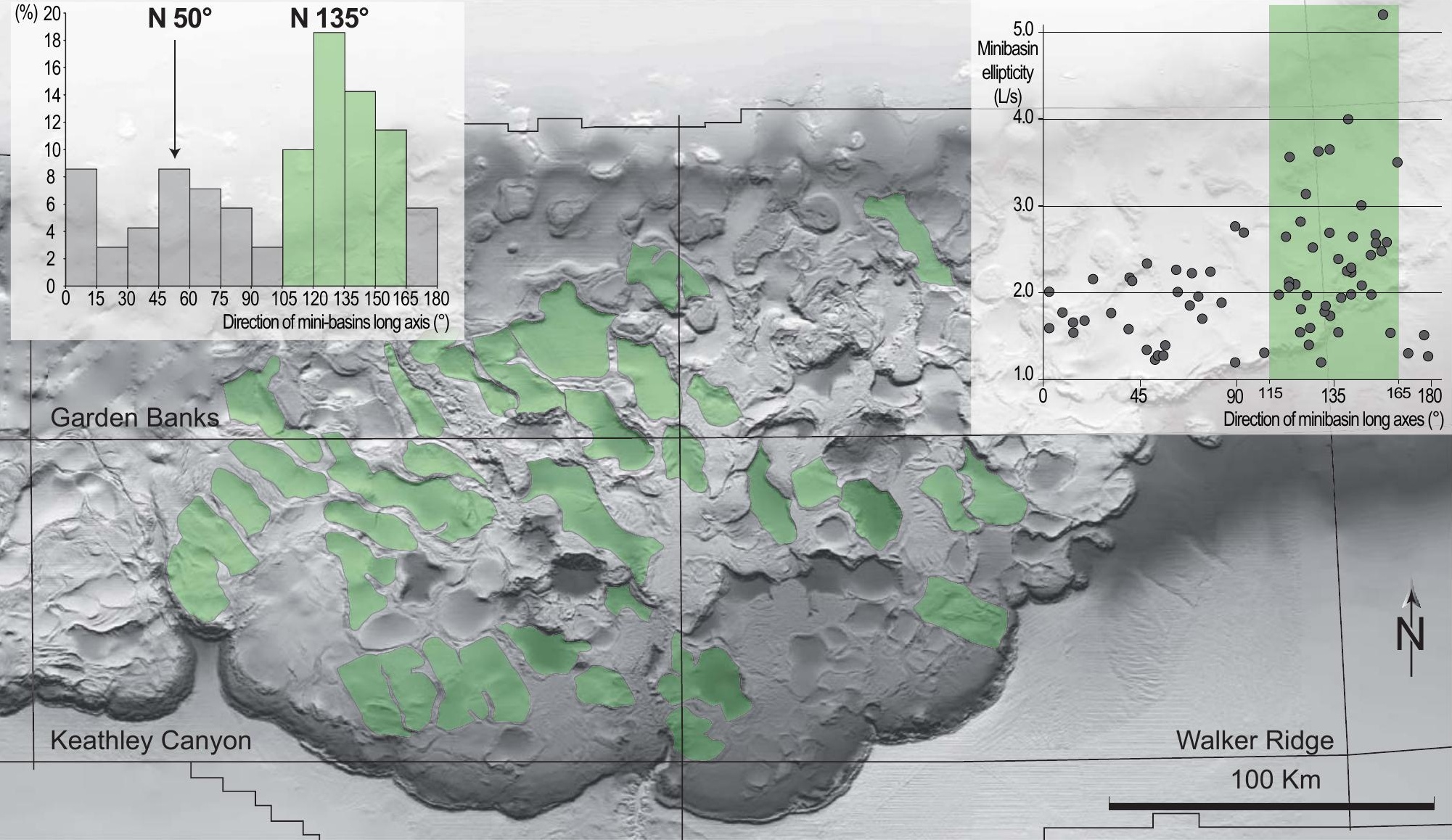


En échelon faulting
En échelon folding

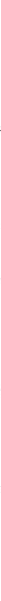




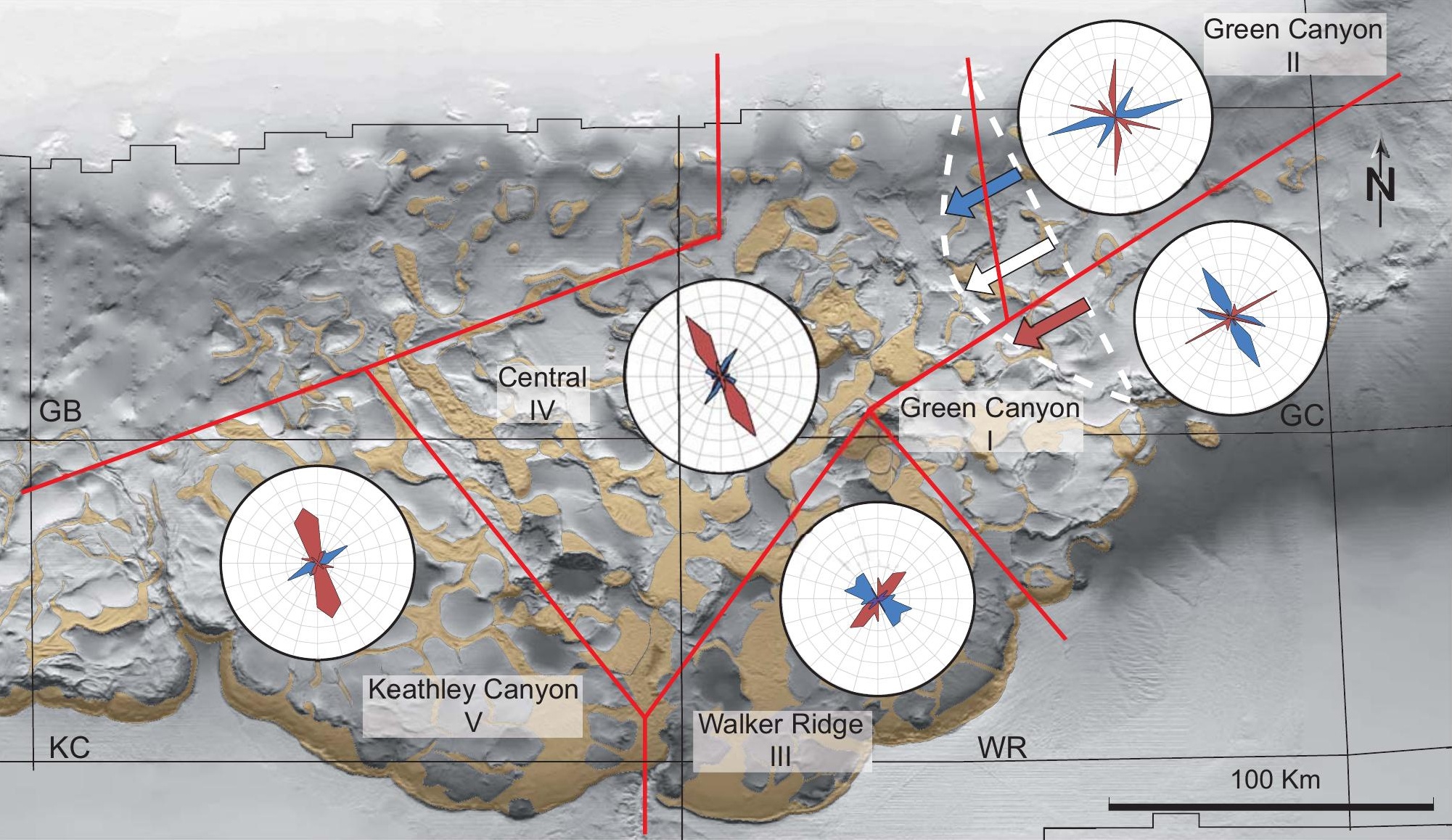





\section{Downslope}

Upslope

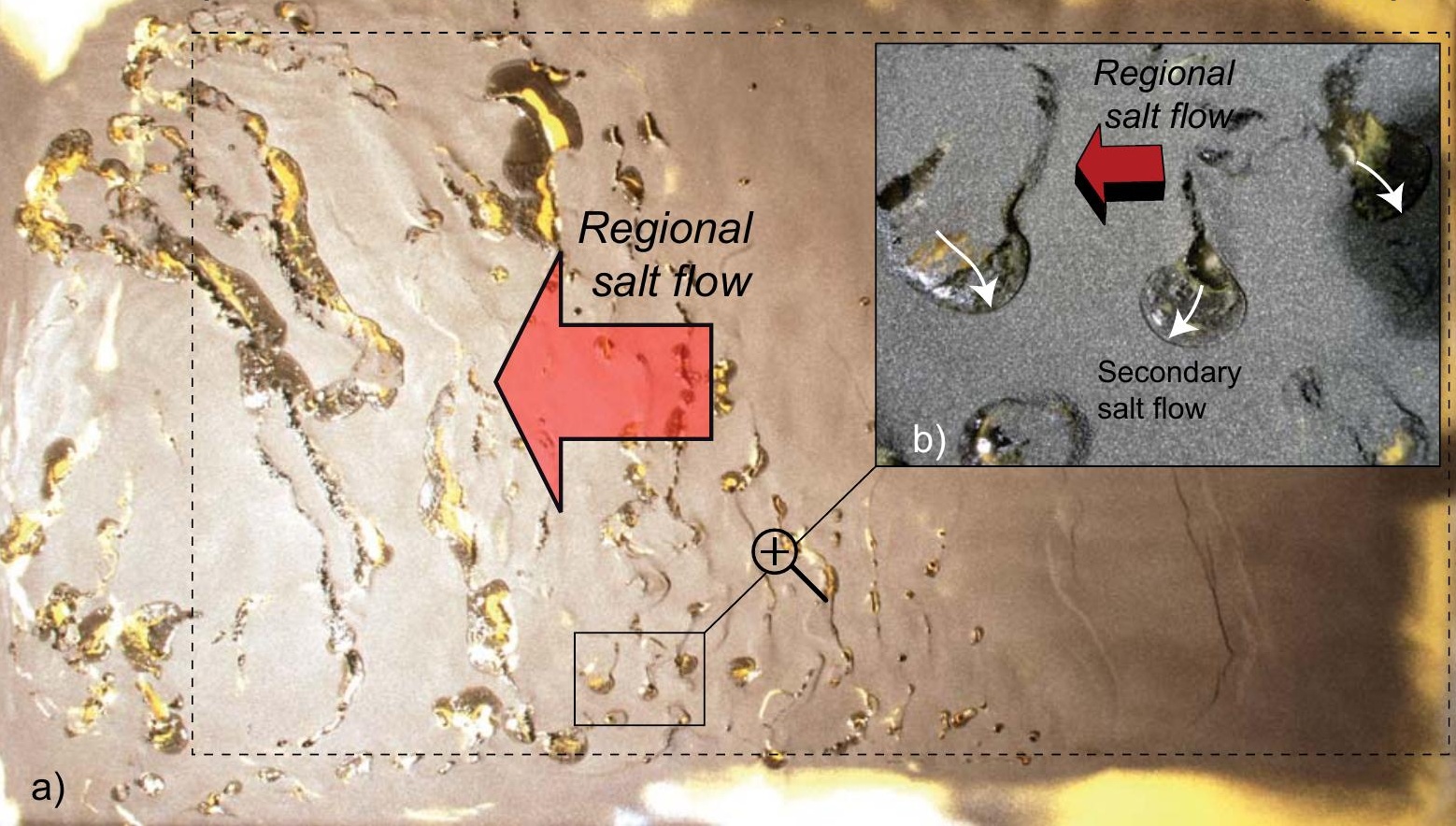



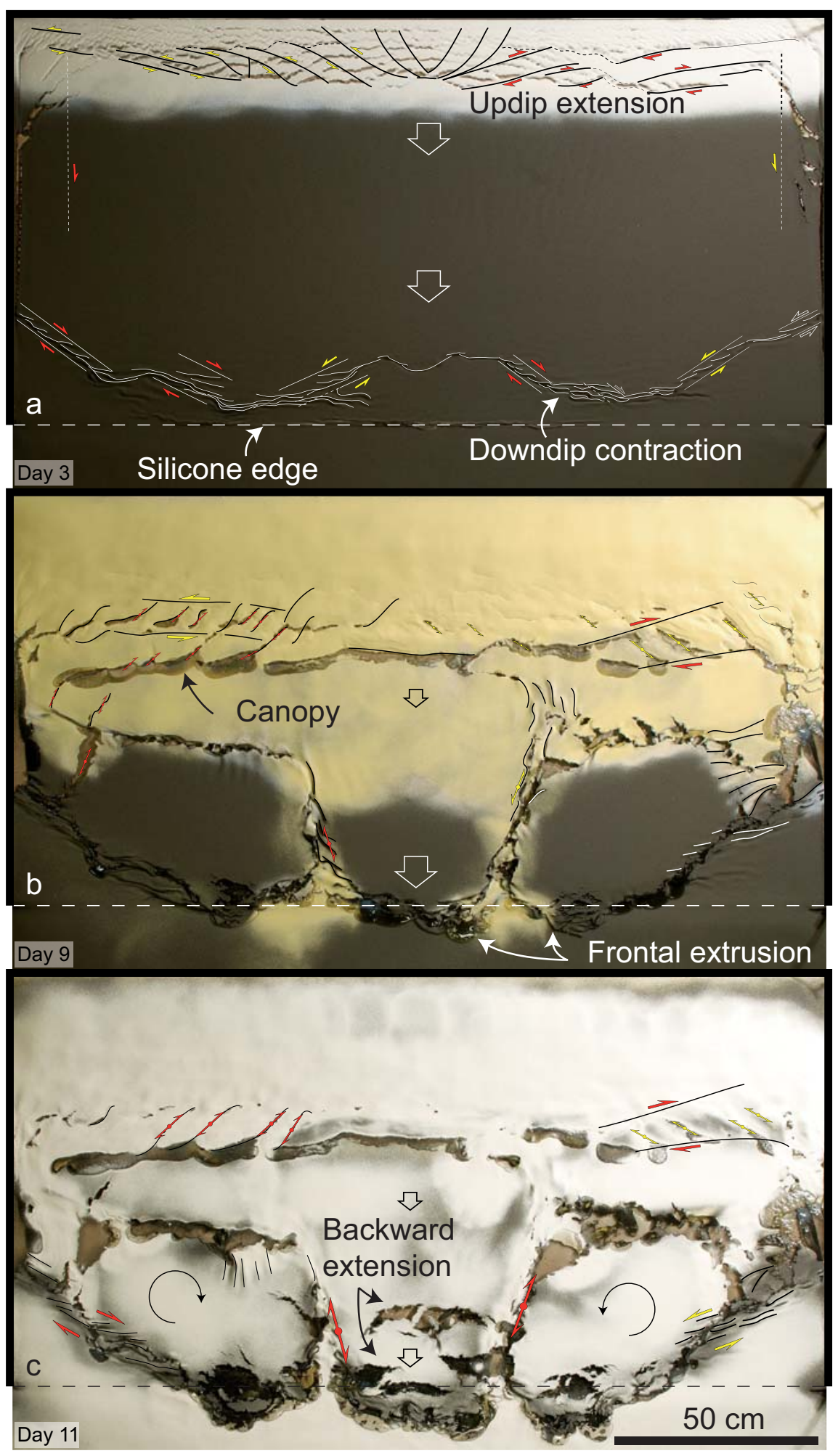
$\mathrm{NE}$

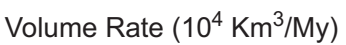

Present day shelf break

\section{Salt Nappe}

Profille B

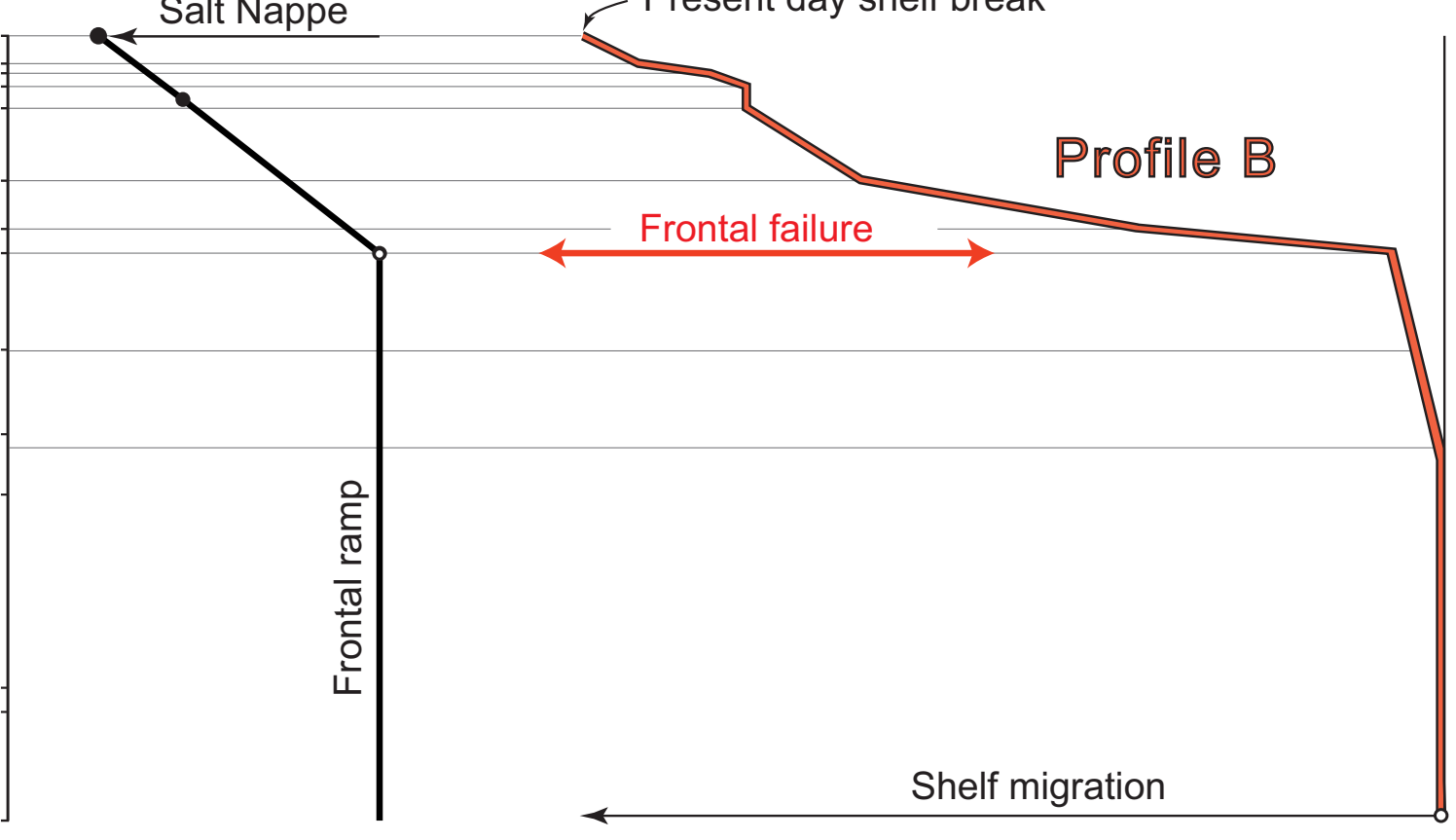




\section{a) North American Margin}

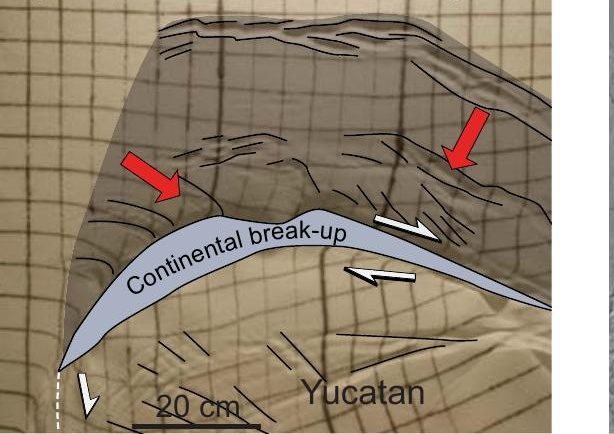

b) North American Margin

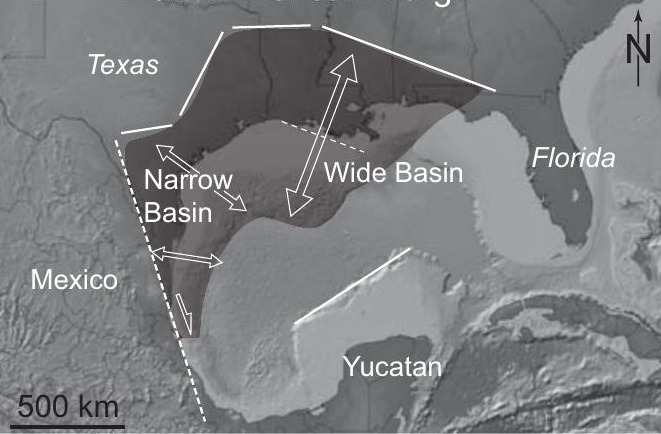


